\title{
Weaving new retail and consumer landscapes in the Scottish Borders
}

Anne Findlay* and Leigh Sparks

Paper prepared for submission to the Journal of Rural Studies

* contact author

Institute for Retail Studies

University of Stirling

Stirling FK9 4LA

UK

Phone: 01786467386

Fax: 01786465290

Email: a.m.findlay@stir.ac.uk 


\title{
Weaving new retail and consumer landscapes in the Scottish Borders
}

\begin{abstract}
:
New retail locations and formats and changing consumer capabilities and behaviours (including 'switching') have encouraged “outshopping” from rural to urban areas. Rural areas have been suffering from a decline in the provision of services, including retailing. One 'solution' has been the strengthening of market towns in rural areas by the development of new major retail stores. The effects of this are perhaps not fully understood, particularly where the rural area comprises a network of towns rather than a single centre. Three comparable consumer surveys (1988, 1998, 2004) of shopping behaviour in the Scottish Borders are analysed. Consumer place and store switching data are used to examine the impact of new retail opportunities on shopping patterns. Two different switching strands are identified: clawback and redistribution.

Redistribution within the rural network is a new finding.
\end{abstract}

\section{Keywords:}

Rural, retail, market towns, planning, Scottish Borders, switching, outshopping, clawback 


\section{Weaving new retail and consumer landscapes in the Scottish Borders}

Retailing in rural areas is a key service provision and shopping is a key consumer activity. Changes in retailing trends and consumer behaviours have led to difficulties in establishing adequate retail provision in rural areas. The decline and closure of local and village stores, the problems of traditional small town high streets and perceived high levels of "outshopping” from rural to urban locations are all symptoms of the problem. Amongst the solutions proposed has been the strengthening of market towns by the addition of new major retail facilities, often adjacent to the existing town centre (Powe and Shaw 2004). Market towns would thus act as a focal point for the rural community in terms of service provision and in stemming travel and outshopping to urban centres. These new stores “clawback” spend from the urban centres and thus enhance service provision directly and indirectly in rural areas.

Major new retail developments are however an emotive topic. They have been both denounced and welcomed in market towns and rural areas. Some view them as a threat to local businesses and as suburbanisation of the rural (Fyson, 2006). Others see much needed investment in an ailing rural economy and a life line for rural areas bypassed in the modernisation of retailing and the new patterns of consumer behaviour. Major retail developments often epitomise all that is not rural, except in 'generic' geographic locational terms. At the same time however they may contribute to the reassertion of place identities at the market town or rural area level.

The aims of this paper (and thus its contribution) are to document changing retail and consumer landscapes through the results of survey work in the Scottish Borders in 
1988, 1998 and 2004 and to understand the interactions and implications of these changing situations on this rural area and its consumers. To meet these aims, the paper is structured into five sections. First, the research background is introduced in terms of retailing, market towns and rural retailing, and then the concept of consumer store switching behaviour. Secondly, a brief description of the study area and of the sequence of surveys is provided. Thirdly, the results from the surveys are presented. Fourthly, the key issues of the results are discussed from a variety of standpoints and concepts. Finally, conclusions are drawn.

\section{Research Background}

\section{(a) Retailing Change, Market Towns and Rural Retailing}

Retail and consumer landscapes are in a constant state of flux and tension. Most consumers exercise degrees of choice on a daily, weekly and monthly basis as they purchase products and services. Some consumers, due to a variety of circumstances, often related to physical or economic accessibility, may be unable to exercise much choice. Retailers through their success or otherwise in attracting consumer spending, make money and remain in business (or not). The competitive battle for consumer spending involves retailers changing their retail offer, product assortments, branding and even location as they seek to capture consumer spending, market share and profit from other retailers. The development of new retail methods, formats and locations makes and re-makes retail and consumer landscapes. Consumers react to such developments by changing previous patterns of behaviour and by altering their locational and/or store spending patterns and loyalties. Even retailers not involved in new retail practices or developments are thus affected by changing consumer perceptions, preferences and behaviours. 
Some retail changes are generally uncontroversial e.g. stocking a new line of products. Other developments e.g. a new food or non-food superstore, require retailers to be willing to invest and develop stores and local and national land-use planning regimes to provide permissions to allow the development to take place. When new locations become successful, this success can attract other retailers to locate in proximity, reinforcing changes in patterns of consumer movement and behaviour. New shopping developments may change not only the consumer perceptions of retail centres, but they may also alter broader perceptions of, and preferences for, places. Retail and consumer landscapes are thus transformed by both competing and enabling forces. Rural areas are affected by such developments even when they are in proximate accessible urban areas rather than the rural area itself.

In research terms, the development of new forms of retailing (e.g. superstores and hypermarkets, discount stores, shopping centres) over recent decades has been a focus of study (e.g. Burt and Sparks, 1994; Fernie, 1998; Dawson, 2000; 2001; Thomas et al 2006; Wood et al., 2006). There has been considerable concern expressed over the individual and cumulative impact of these new developments and formats, particularly on smaller retailers (e.g. APPSSG, 2006) and on rural areas and market towns (e.g. DETR, 1998; Powe and Shaw, 2004; Phillips and Swaffin-Smith, 2004). In food retailing concerted lobbying has led to a second Competition Commission enquiry into the sector within six years (Competition Commission, 2006), focusing on the use and possible abuse of retailer power (Burt and Sparks, 2003) and the competitive impact of large retailers. These analyses of retail change have recently been complemented by studies of consumer choice and behavioural change of 
consumers over longer time-spans (Clarke, 2000, Clarke et al., 2006; Jackson et al., 2006). Retailing and consumers have changed. Some of the ways in which they have changed are understood. Rarely however have these elements been put together and even more rarely in rural contexts.

A number of authors (e.g. Byrom et al., 2001; 2003, McEachern and Warnaby 2006) have noted that research into rural retailing generally is rather dated or takes place as a by-product of work on independent or small shops generally (e.g. Dawson and Kirby, 1979; Smith and Sparks, 1997). Recent specific research tends to focus somewhat on Scotland and develop three main themes: issues of food availability and choice (e.g. Skerratt, 1999), particularly in remote rural areas (e.g. Clark et al., 1995; Byrom et al., 2001); the impact of “outshopping” (e.g. Broadbridge and Calderwood, 2002); and strategic options for retailers (e.g. Byrom et al., 2003). In terms of retailing the common issue would appear to be the maintenance of adequate facilities in the rural area. Policy focused research has additionally emphasised the importance of the quality of service provision and highlighted demand for greater choice of services in the immediate rural areas (Accent Scotland and Mauthner, 2006).

Much attention has been given over a long period of time to the survival of the village store (e.g. Kirby, 1981), but more recently the significance of retail and consumer changes on market towns has been recognised (e.g. DETR, 1998; Powe and Shaw, 2004; Phillips and Swaffin-Smith, 2004). As the campaign group Action for Market Towns (2006) state:

'Small towns are important. They are critical employment and service centres for the countryside, and they serve up to a quarter of the nation's population. Yet these towns face many challenges - loss of services due to centralisation, out-of-town shopping, 
and car parking and traffic congestion. All are obstacles to prosperity that threaten vitality and viability’

Market towns can play a central role in rural regeneration (Powe and Shaw, 2003) and act as the focal point for the provision of services for rural areas (Powe and Shaw, 2004). There are a number of studies focusing on issues such as managing small and market towns, the role of partnerships, how to counter decline, the relationship between different service functions, the impact of shopping developments, and ways to increase loyalty to local market towns (e.g. Caffyn, 2004; Collis et al., 2000; Hallsworth and Worthington, 2000; Phillips and Swaffin-Smith, 2004; Powe and Shaw, 2003; 2004; Thomas and Bromley, 1995; 2002; Worthington, 1998). Whilst important and interesting, this literature does not perhaps fully integrate retail and consumer developments in terms of behaviours and networks of locations and activities.

Market towns provide services both for the town population and for the rural hinterland. As rural services including retail provision have declined and populations have become more mobile so the retail structure and consumer behaviours have adapted. The study in this journal by Powe and Shaw (2004) of Alnwick, in Northumberland, looked at key aspects of the market town which attracted shoppers. They concluded that food shopping choice was of paramount importance and that there was an opportunity for such towns to extend their retail provision so as to better service rural areas. This provision of new facilities concentrates provision, but within the broader rural area and so provides a better overall level of local rural service. The full impacts of such an approach have however not been considered. 
McEachern and Warnaby (2006) advocated a continuum approach to rural and urban retailing rather than a dualistic conception of urban or rural retailing, championing the term relative rurality. This paper, very much aware both of the diversity of ruralities which exist (Halfacree, 1995) and the diversity of the rural in geographic terms from remote to accessible (Scottish Executive, 2006) prefers a more plural view that looks at how the non-rural is accommodated within the rural, through a process of shopper redefinition of the market town, and local rural area, rather than through a redefinition of ruralities.

\section{(b) Concepts of store switching}

Retailing and consumer practices have changed. In this context, key related concepts are "switching”, “clawback” and "outshopping”. Retailers are often engaged in the development of customer loyalty to try to prevent consumers switching their shopping amongst stores. However it has been shown (East et al., 1995; 2000) that switching occurs to some extent all of the time, but is associated in particular with changes in store operator or new developments. In some cases a new development could lead to a complete re-evaluation of all store attributes by consumers (Seiders and Tigert, 1997; Arnold et al., 1998). New developments are predicated on encouraging consumers to switch their shopping from one store and/or location to another. Some of this will involve what is termed "clawback”, whereby spend that currently occurs outside an area, such as to a neighbouring town or city, (“outshopping” or "leakage” - see Lumpkin et al., 1986; Guy, 1990; Jarratt, 2000) is attracted back (“clawback”) to within the area. The mechanism for this is consumers "switching” their spending, enabled by the development of retail opportunities more appropriate to their needs or a re-assessment of their preferences. The perception and reality of clawback (and the 
underlying switching behaviour) depends to a degree on the spatial scale that is considered.

In rural areas the changing pattern of retail provision and other demographic, population and behavioural changes have reduced local provision e.g. village shops, affected market town high streets and increased outshopping to more modern facilities in, or surrounding, large cities, other workspaces and major towns (Findlay et al., 2001). Retail provision in rural areas and market towns has reduced and the spend in such locations has fallen (Powe and Shaw, 2004). One reaction to this has been the potential for market towns to focus rural service provision and retail development by introducing new major retail facilities e.g. superstores and retail warehouses, with the aim of retaining spend in the rural area as a whole and reducing the outshopping (via clawback) to cities and other locations outside the rural area.

Clawback is thus a key variable in the redistributive impact of new retail development. Most large-scale retail development applications are supported by retail impact assessments which quantify the need for the development based on levels of potential local spend and the level of existing retail provision. The argument is often that the current customer base can support an increased provision of retail space. Achieving this will of necessity demand redistribution of retail spend i.e. the switching of place where the product range will be purchased. If this is to a more local location, then the emphasis is on a reduction in outshopping, mainly expressed as clawback. Land-use planners have often been enthusiastic about new major retail developments in rural areas, having felt disenfranchised from modern retailing. They often maintain that clawback will occur for their area, and thus promote jobs, local 
services and local prosperity. However, the potential for clawback may be more limited than claimed. New developments may result instead (or additionally) in substantial and perhaps unexpected reshaping of the local network of retail and town centres. The nature and implications of place based switching however has been little studied in the context of market towns and rural areas and certainly not in the context of a network of market towns in a rural area.

It is within this broad area that this paper is therefore set. It reports on a sequence of surveys undertaken since 1988 in the Scottish Borders local authority region. These consumer surveys allow the pattern of macro-level consumer spending behaviour change to be identified and described. The interest here is in the general shopping behaviour and not the detailed store specific or consumer preference issues. The changing structure of retailing, as partly enabled by land-use planning, can be used to explain these changes in consumer patterns. The 'new' retail structure is in part derived from the vision of the local planning authority through its planning permissions and structure and local plans and its desire to 'modernise' the retail structure of the rural area, to meet changing consumer behaviours and demands, and to obtain clawback of spend. Such a vision has then to be accepted and embraced by consumers. There are thus a variety of actors (planners, retailers, consumers) involved in creating or "weaving" the new retail and consumer landscapes or fabrics of the Scottish Borders.

\section{The Scottish Borders and the Retail Surveys}

The Scottish Borders occupies the south-eastern portion of the Scottish mainland and is an historically and culturally rich area. Unlike many other parts of Scotland, the 
Borders is not dominated by any one major centre, but is rather a network of smaller market towns with a rural hinterland. It is essentially rural in character but has been influenced to the south by the English towns and cities of Berwick-upon-Tweed and to a lesser extent Carlisle and Newcastle, and to the north by the Scottish capital, Edinburgh (Figure 1). Historically and culturally the market towns perceive themselves as being in conflict and competition amongst themselves, though there is a "Borders' mentality” which sets the area apart within Scotland and sees the region as distinctive and special (e.g. Fraser, 1971). Many of the towns have links in the past to textile industries, though this sector has been in decline for some time. Pike (2002) provides a view of economic development in the Scottish Borders and of the planning and support mechanisms attempting to change the focus of the region (and how these differ from the English Borders) and to develop the rural economy and market towns.

The population of the Borders Regional Council area is 106764. This population is widely dispersed with the largest centres being Hawick (population 14,573) and Galashiels (population 14,361) (www.scrol.gov.uk). The population centres act as retail centres in a network of locations. In recent years, Galashiels has seen the most extensive retail development (see below). A key concern of the local authority, as stated in its structure plan (Scottish Borders Council, 2002), is to "enhance the shopping facilities in the Scottish Borders to reduce the leakage to other areas of spending from residents, employees and visitors”. The policies that attempt to do this might best be described as nationally following, focusing as they do on the key national retail policies of development and enhancements in town centres, limited outof-centre retail development if no other sites available and encouragement and some support for village shops. 
The development of the retail structure in the Scottish Borders has not been the subject of much study. Until the 1980s the developments appeared to follow classic small shop rise and decline patterns focused in and around the market towns and developing local population districts. Major retailers, other than the local Cooperative were mainly absent or low-key. Stores were small in scale and came under increasing pressure from newer developments beyond the boundaries of the Scottish Borders Region in for example Edinburgh, Newcastle/Gateshead and Berwick-uponTweed. The first food superstore (Safeway) opened in Hawick as late as 1993 (Findlay, 1993; Smith and Sparks, 1997), though Safeway had by then developed a network of smaller central shops in the main market towns. Tesco entered the Borders in late 1999 when they exchanged stores in Angus for the Lothian, Borders and Angus Co-operative Society superstore in Galashiels (which was opened in 1983 as a smaller store and expanded to a superstore in 1995). This perhaps surprising and controversial deal saw the local Co-operative society accused of attempting to derail other superstore developments in the town (Scotsman, 2000). The Co-operative Society retains a strong presence through a network of smaller stores. In non-food the main developments have been in the 1990s when ex-mill land and sites in Galashiels were developed. Wilders Haugh is the site of B\&Q, the first of these developments. Retail warehouse parks opened at Comely Bank Mill (main tenants: Carpetright, Currys and Matalan (replacing MFI in 2003)) and Hunters Bridge (main tenants: Comet, Allied Carpets, Halfords and Sports World). Shop numbers in Galashiels have been rising since the late 1990s whilst in Hawick they have been declining, in fact reversing their relative positions with shop numbers in Galashiels now exceeding those in Hawick 
(Scottish Borders Council, personal communication). There has been a concentration of new major retail provision on Galashiels and a stronger local retail sector.

The Scottish Borders Council (which was the Borders Regional Council until reorganisation in 1996) commissioned the Institute for Retail Studies at the University of Stirling in 1998 to undertake a replicative postal sample household survey to understand the shopping patterns in the Borders and to inform policy development. The previous survey had been undertaken in 1988 and as much access as possible to the results of that survey was provided in 1998. However, when local government reorganised in 1996 the original data went missing. In 2004 the University of Stirling again mounted a replicative survey as part of a wider programme of looking at consumer shopping change in Scotland.

The survey methodology in each case was a Borders wide c10\% sample household survey involving a postal questionnaire. The same questionnaire has been used in all three surveys with the exception of some modifications in 1998 and 2004 to take into account new retail locations (both) and internet shopping (2004). In 1998 there was a 32\% response rate (1402 questionnaires) and it is known that the response rate was higher in 1988. In 2004 the response rate was lower at 15.4\% (580). In addition, in 2004 there was a marked lower response rate from households in postcodes near to Berwick-upon-Tweed, for reasons that are unclear. The long-term reduction in survey response rates is a common refrain (e.g. Parry et al., 2001).

The surveys are we believe comparable. Comparisons with appropriate census data do not show any significant population differences for the Borders as a whole. These are 
not matched surveys of households over the period (i.e. they are not strictly longitudinal but are rather snapshots in time). However the consistency of the survey instrument over the time frame provides a core basis for comparison. We however recognise that in the 2004 results there may be a minor under-reporting of the shopping patterns with regard to Berwick-upon-Tweed and a consequent but lesser over-statement of the results for locations in the west of the Borders area.

\section{Survey Results}

In recognition of the importance of food shopping to people's everyday lives and as a proportion of retail spending, food shopping is analysed separately from non-food shopping. A third section on home based shopping completes the analysis.

\section{Food shopping}

The period between 1988 and 1998 saw the development of a number of small, central Safeway stores in selected market towns in the Borders and the opening of The Gyle Shopping Centre at Edinburgh with its flagship Safeway and Marks and Spencer stores (Roger Tym \& Partners, 1996). As noted earlier, the first Tesco in the Scottish Borders did not open until 1999. More generally, the period 1988-1998 was one where the car took over almost totally as the main mode of travel to shop, because of its wider availability, presumed convenience and the reduction of bus services and walking to shop. Table 1 shows how these general and specific changes created a new consumer landscape in the Borders over this period.

Between 1988 and 1998 there was a slight concentration in the destinations for main food shopping, but a marked variation in the mode of travel to shop. By contrast, 
convenience food shopping demonstrated a broader spread of locations with comparatively limited variation between 1988 and 1998, or even to 2004. Main food shopping however switched markedly between 1998 and 2004 as the impact of the Tesco superstore was felt across the Borders. Table 1 shows a dramatic increase in the market share of Galashiels between 1998 and 2004, both in terms of main trip destination and percentage of main trip spend. The proportion of respondents shopping in Galashiels rose to 40\% in 2004 from 23\% in 1998 (and 1988). This market share gain has come from other centres in the Borders, in particular Hawick and Kelso. Share of spend showed that these towns had a lower proportion of share of spend than the use of the location, e.g. Kelso attracted 7.6\% of shopping trips but only $4.9 \%$ of spend. In the case of Hawick proportion of spend declined more rapidly than trips to of the centre between 1998 and 2004. It is notable in the table that modal shift occurred between 1988 and 1998, but shopping location and spend shift occurred between 1998 and 2004. This would seem to point directly to the impact of the development of the Tesco store at Galashiels.

One of the arguments put forward by developers, retailers and planners in pursuing food superstore development is that it permits 'clawback' of existing outshopping. This ‘clawback’ occurs as consumers switch their shopping trip patterns and store choices, i.e. 'clawback' requires shifts in actual behaviour. Table 1 suggests that clawback has operated at various levels. If the intent was to 'clawback' trade from Edinburgh and Berwick, then it would seem that the impact was instead to redistribute and concentrate trade within the Borders. Edinburgh had 6.4\% of trips in 1998 and $5.4 \%$ in 2004, representing only a comparatively minor change and a change from $11.5 \%$ to $10.2 \%$ in terms of share of spend. It is notable that those undertaking their 
food shopping in Edinburgh (and here this includes new stores and locations such as at Dalkeith) are the highest main food store spenders, with share of spend proportions outstripping location of spend. Edinburgh's main food market share was thus barely affected or 'clawed back' after 1988. One explanation of this is that the surveys show that Edinburgh has the highest proportion of shoppers who chose their main food store based on proximity to work (see also Findlay et al., 2001).

The main effect of the food superstore development in Galashiels has been to redistribute food shopping behaviours and to create a new consumer landscape amongst the Borders network of market towns. The effect has been to concentrate and reduce the catchment zones (in postcode terms) for the main market towns of Kelso, Peebles and Hawick, but to broaden the catchment zone and deepen the penetration for Galashiels (Table 2). Main food shopping has been localised with the exception of the Galashiels superstore. Galashiels gained $47.9 \%$ of trade from the principal postcode patronising the town in 1998 but only $40.5 \%$ by 2004. By contrast the comparative figures for Kelso were 75.9\% for 1998 and 92.9\% for 2004. Galashiels has become a stronger destination or node in the network of centres, focusing the food shopping patterns of the Borders.

The modernisation of food retailing in the Borders with the Tesco superstore thus altered the consumer and retailer landscapes. Consumers decided to shop at this new operator and this new location. As has been seen, this has affected market shares for the towns across the network. It has also had more detailed effects associated with modernisation, scale and operator. Consumers re-evaluate choices when major events, such as a new store opening, occur (Seiders and Tigert, 1997). In the case of the 
Tesco opening, this re-evaluation and changing of behaviours appears to have been socio-economically configured. Table 3 demonstrates that the respondent profiles for the Safeway in Hawick between 1998 and 2004 altered markedly. For example the professional and managerial group fell from $34.8 \%$ of trade to $26.4 \%$, whilst retired people patronising the store increased from $26.0 \%$ to $35.8 \%$. In Safeway in Hawick the patronage from people aged less than 40 declined from $29.6 \%$ in 1998 to $17.0 \%$ by 2004. By comparison, the Tesco in Galashiels 'creamed off' the more affluent and also the younger consumers, with $42.6 \%$ in the professional and managerial group and 23.0\% aged less than 40 . Though not shown in the table, a comparison between respondents using the Co-operative in Galashiels and the Hawick Safeway in 1998 showed no statistically significant differences. By 2004 differences between the Tesco and Safeway shopping respondents in the two locations were statistically significant. The two companies in 2004 more closely followed their national shopper profiles (Nielsen, 2006). This was reflected in spend patterns where in 1998 the spend at Safeway in Hawick was $12 \%$ higher than in the Co-operative in Galashiels, whereas by 2004 the Tesco Galashiels spend was 29\% higher than the Safeway Hawick spend. In effect categories of consumers are isolated from the new retail development and have to rely on existing provision, if it survives. There are thus degrees of consumer concentration and polarisation.

This switching behaviour, concentrated as it is on certain categories of consumers has further implications. As the spend pattern alters so the amount 'left over' after the main spend changes. In this case it would indicate that there is a reduction in spending potential outside Galashiels and in local small and village stores. Additionally, there are effects on retail job numbers and locations. Data from Nomis 
(www.nomisweb.ac.uk) show that retail employment has declined in many of the Borders postcodes, though not across the Borders as a whole. There has however been retail employment growth in Galashiels. 'Switching' behaviour by consumers has wider implications therefore, above simply competitive effects amongst retail operators.

\section{Non-food Shopping}

The major retail developments in non-food have involved significant investment in retail warehouse parks in Galashiels, as noted earlier, and major developments around Edinburgh (Gyle Centre, Newcraighall and IKEA at Straiton), which would be accessible by car from much of the Borders. Across all non-food sectors, travel by car increased substantially between the 1988 and 1998 surveys, with commensurate declines in travel by foot and to a lesser extent by bus. The surveys suggest that whilst foot traffic has fallen further since 1998, the decline in bus travel has been slightly reversed, though not to 1988 levels. Travel by foot fell from $15.7 \%$ of main trips for clothing and footwear shopping in 1988 to $6.0 \%$ in 2004. Similar patterns are seen for electrical goods (20\% to 5\%), DIY (16.9\% to $7.0 \%$ ) and furniture and furnishings (15.4\% to 8.1\%). These modal shifts also represent spending shifts away from local town centre and local stores.

The market shares in destination terms for non-food shopping show a concentration of trips on Galashiels and on Edinburgh (Table 4). Clawback from Newcastle, Carlisle and Berwick upon Tweed has been important. Edinburgh has increased its importance in three non-food sectors although the timing of the 'switching' has varied. In the case of furniture and furnishings there is a clear effect of IKEA opening 
at Straiton south of Edinburgh, identified directly by respondents. In the fourth sector, DIY, the opening of a B\&Q store in Galashiels produced significant spending 'clawback'. In all four sectors the concentration process within the Scottish Borders is well marked and would appear to be linked to the mode of travel. The reduction in the 'others' category masks the concentration within the Borders on to selected centres (particularly Galashiels) but also hides the decline in significance of centres such as Newcastle and Carlisle beyond the immediate area. The emergence of major non-food retailers within the broad town areas of the Borders has altered the network dynamics considerably, allied to higher levels of car access to key centres in and around Edinburgh. Edinburgh trade, with the exception of the DIY sector, has not been 'clawed back' to the Borders. Indeed the outshopping to Edinburgh seems to have increased over the survey period.

As before, the impacts of these changes go beyond where people travel to and spend money, as important as these are. Local centres have declined as externally Edinburgh and internally Galashiels have become more attractive. Local retailers have reduced in significance as multiple chains have moved in to the area, and have extended their presence in and around Edinburgh. The breadth of retail provision across the Borders has been affected.

\section{Home-based Shopping}

Thus far the examination of changes has focused on new major shopping developments attracting mobile consumers. The 1998 and 2004 surveys permit however some comparison of shopping at or from the home, including Internet shopping in the 2004 survey. The data are inconclusive. Internet grocery shopping is 
miniscule in the 2004 survey and focused on postcodes nearest to Edinburgh. Fewer households reported having any home delivery in 2004 than in 1998 (48.7\% in 1998 vs $42.1 \%$ in 2004). There was an increase however in the use of mobile shops (12.4\% to $27.8 \%$ ) particularly for groceries and vegetables. Mail order for clothing and footwear was also at identifiable levels.

Explanation for these figures may lie in changes to access modes and the concentration of catchments noted above. There could be reductions in choice sets for those without good access and who remain reliant on local stores, thus increasing non fixed-store usage. The new network nodes in effect reinforce either positive or negative effects and amplify the changes in the fabric of retailing, thus affecting consumer possibilities and choice. As competitive effects occur so choice sets may reduce, forcing reliance on alternatives, whether local or 'virtual'. The lack of evidence for one newer alternative, the Internet based home delivery services now offered by many retailers, may simply reflect timing or could also be based on lack of technological penetration in this rural area at the time of the survey.

\section{Discussion}

The results presented earlier show the outcomes at points in time of decisions consumers make over their spending in shops. The results show the ongoing battle for share and spend amongst retailers. Switching patterns have identified two very different processes at work. The first of these is clawback which has been previously identified as being significant and desirable in cases such as the Powe and Shaw (2004) study of Alnwick. The second is spending redistribution amongst smaller towns in the region. This is a very different type of switching, which in this case is 
based on a process of concentration of retail facilities. The findings emphasise the concentration of spending on one market town (Galashiels) and the contracting catchment zones for all the other market towns. By inference (though supported by other work e.g. Smith and Sparks, 1997; Hare, 2003) there are implications of these changes for rural village stores, sections of the community, character of the market towns and even the Borders way of life. All of these findings are of interest and importance, but as with much of the previous work cited, they tend to underplay the dynamics and inter-relationships of the situation and the nuances of how retail and consumer landscapes have been created and are inter-woven.

Planners are concerned with spatial networks of places, their health and vitality and the competition amongst these places. "Clawback” from outside is an over-riding principle, at various scales. Retailers are interested in networks of stores, competition amongst operators, levels of productivity and profit margins. Some have more power and influence than others. For the most part multiple retailers are looking for modern premises, larger than those in traditional high streets and operating at a scale which demands a customer base larger than most single market town populations.

Consumers are keen to meet their perceived needs and thus operate, if mobile, within a repertoire of spaces and shops. Traditional associations and loyalties for many have no current resonance and the repertoire and its use may reflect this.

Planners have traditionally been reactive rather than proactive in their attitudes to retail development. Increasingly they are being encouraged, although not necessarily enabled, to be more proactive. Major retailers are proactive, actively seeking new technological advantages, marketing techniques, market positioning and development 
opportunities. Whilst retailers are well informed on planning matters, planners are far less well informed on retail matters (Findlay and Sparks, 2002). Consequently planning decisions do not necessarily reflect an understanding of how a store will change shopping patterns as a result of store switching. Similarly much previous work has focused on clawback and not on redistribution, possibly because the research has been based on single, as opposed to a network of, market towns in rural areas.

Local planners, multiple retailers and consumers in the Scottish Borders have been engaged in changing the retail and consumer landscapes. The shoppers or consumers have activated this new retail landscape through the process of store switching. Consumer switching behaviour legitimises the activities of retailers and those of the planners in turn. The fact that switching has produced not only a new (and perhaps different from expected) patronage pattern but also a differentiated landscape of shopper profiles, is important for future policy development.

Sir Terry Leahy (CEO of Tesco) has consistently justified Tesco’s expansion and operating scale achieved on the basis that customers are their constituency and have choices to walk away if unsatisfied. However as evidenced by the contrasting store experiences and 'loyalties’ of Safeway in Hawick and Tesco in Galashiels, switching behaviour is nuanced, varying with operator and situation. The particular switching patterns and the resulting shopper profiles reflect the depth of penetration of any particular retailer. The extent to which a shopper profile is exclusive or inclusive, narrow or broadly based, will reflect the legitimacy of the network. Differentiation in the Scottish Borders since the opening of Tesco in Galashiels has been legitimised through the shopper switching process. A significant and broad segment of shoppers 
has embraced the decisions of the planners and retailers. The retail landscape of the Scottish Borders is being 'stitched together' in a new way. Although land-use planners cannot discriminate between retailers in deciding on applications they can begin to take account of the likely planning outcomes of particular investments in the perspective of their local place networks. They need to realise that different operators and formats will be engaged differently.

By placing such an emphasis on switching we raise new questions. Implicit in our study is a view that the Tesco entry to Galashiels was fundamental. However from a planning perspective, this entry was serendipitous, brought about by a swap of stores between two organisations. Would the pattern of shopping redistribution have been quite as transformed as it was if Tesco (the dominant retailer in the UK) had not become involved? But then, how might the network have been later altered by a Tesco entry to a different site, possibly in a different town? From a planning perspective does adding further new stores with different operators add value in terms of for example clawback? Or is it that having preferenced one network node (Galashiels), local politics ensures that other nodes (Kelso, Hawick) have also to be developed similarly? From the consumer perspective research concerning service provision in market and small towns shows an unfilled demand for greater variety of choice and products. The perception is that choices and range of products is poor in market towns (Accent Scotland and Mauthner, 2006). Such consumer perceptions leading to continued leakage and outshopping, pressurises planners to continue to meet demands to suitably "enhance” the network, whatever the consequences on existing patterns and forms. 
The entry of large modern retail forms into market towns is of course controversial. Here, the process has lead to a concentration on Galashiels as the primary retail centres, to the detriment of other towns. But, there is also an impact on the character of the market towns through the introduction of the new formats and multiple retailers. This impact goes beyond competitive and switching behaviour impacts to the heart of the nature of the high street in a market town in a rural area. For Galashiels there appears to be spin-offs and vitality, but for other towns the situation is not as viable.

Success of course breeds success. Seeing Tesco attracting shoppers to Galashiels, other retail chains have subsequently been attracted to the town. In Galashiels, ASDA opened a 40,000 sq ft (net) store in November 2006 near to the Tesco (Figure 2). The opening of the Asda store was greeted by the Council Leader as proof that Galashiels was the retail capital of the region (BBC, 2006). This site was the one at the centre of the controversy in 1999 when the Lothian, Borders and Angus Co-operative sold their superstore to Tesco. In granting planning permission, the Scottish Borders Council considered a retail impact assessment which claimed that spending power would be retained in the Borders, rather than leaking to other centres, particularly Edinburgh. A planning officer commented (Scotsman 2004, p9):

"The key retail issue for consideration is not how this proposal would impact on other individual and competing traders, but whether the development would affect the viability of Galashiels town centre as a whole ... effects should appropriately be described as competition, which would increase choice, would be for the overall benefit of the town centre and would enhance the viability of the town centre”.

Tesco has responded by expanding its store in the town to 80,000 sq ft. In this case, despite its obvious popularity as a shop with consumers, Tesco has been the subject of a vociferous public campaign. Tesco's proposal involved the demolition of the 
College of Textiles building in Galashiels ("where generations of Borders weavers and dyers learnt their trade” - Linklater 2005). Despite not being listed or protected, this building has emotional and symbolic meaning for the town and indeed the Borders. The Tesco proposals, despite being agreed by the Scottish Borders Council, came under massive public criticism (see Linklater 2005, Financial Times 2006) resulting eventually in attempts by Tesco to find a compromise involving saving the façade of the building (Southern Reporter, 2006b). Both the ASDA and the Tesco stores will carry enhanced ranges of non-food items, including clothing, thus expanding their impact and network effects.

Further planning applications for other clothing retailers have already been approved on the basis of clawback. For example the planning application for a designer destination outlet development in the vicinity of the Tesco development cites the importance of stemming leakage as one of the Scottish Borders Council's priorities (Scottish Borders Council, 2002). The retail impact statement by the developer claimed that the majority of the trade would be from expenditure that currently leaks out of Scottish Borders particularly to Edinburgh (Scottish Borders Council, 2005). It also suggests the local impact would be minimal as the proposed development is a new retailer to the area and not in direct competition with existing retailers. This could be true, but the fact remains that Galashiels as a retail centre is in competition with the other market towns in the Borders.

Elsewhere in the Borders, the long-running consideration of superstore development for Kelso (which was part of the reason for the 1998 consumer survey) continues. Proposals for superstore development in Kelso on common land and involving the 
moving of an historic house were rejected by the public in the late 1990s/early 2000s. The search for a suitable site has continued. Tesco are keen to open a superstore at a Scottish Borders Council preferred site, but local traders and the local community council prefer another site. The developers for Tesco in their application state: "the project will assist in halting the leakage of trade from Kelso to Edinburgh and surrounding towns, so benefiting the local traders and the local economy as a whole” (Southern Reporter, 2006a). There is a question however of whether all market towns in the Borders could or should have new retail developments of substantial scale, and whether there is the market to sustain them. Cumulative impacts of such developments could also radically affect the local retail provision, though there would also be switching effects amongst the major retailers.

One of the questions that this discussion raises is the situation of local shops and of the food producing sector in the Scottish Borders. There has been little resistance to the new definitely 'urban' retail forms (urban in provenance, format and organisation) becoming established in an area designated as rural, except from the local Cooperative which can always be accused of seeking to protect their own trading position. The rural ‘otherness’ (Cloke, 1997; Philo, 1992) may have been dented more by an assertion of regional identity than the imposition of non-rural retail forms. Local shops in the Borders can be seen (as elsewhere) as casualties in this new landscape. Local agro-food commodity chains (Murdoch, 2000) are likely to have been further marginalised. With consumers outshopping to major multiples then clawback in the main is predicated on bringing such stores and shopping opportunities closer to the local community, whatever the consequences for the local agro-food community. 
In the wake of the BSE crisis there has been a rising tide of concern from consumers over quality and sourcing and growth in organic and local food awareness and purchase. There has been a desire to

"reshape rural spaces to market niche and quality food products, renew supply chain connections and foster 'alternative' channels of food provision” (Ilbery and Maye, 2006, 364).

Places such as Peebles (and Castle Douglas outside the Borders) are attracting attention because of a renewed focus on "local” production, supply and quality. Whilst currently small there is growing evidence of a wider consumer concern over local produce and alternative channels of food provision (farm shops, farmers' markets, box schemes etc). This movement is however in its infancy in the Borders and exhibits contradictions and challenges (Ilbery and Maye, 2005; 2006). In a probable forecast of the future, Ilbery and Maye (2005) contest the dichotomy of conventional and alternative. One of their case cameos is "Galashiels Bakery" who after losing trade in supplying their own stores across the Scottish Borders have turned additionally to supplying wholesalers and a number of Tesco stores, including the one in Galashiels. The retail and consumer network thus co-opts and integrates the local agro-food chain where it necessary and possible. Such developments are likely to continue if a significant number of consumers begin to show desires for such "local” products and supply.

\section{Conclusions}

The consideration of consumer behaviour and rural retailing has often been partial and highly focused on important but single and narrow issues. This paper instead took a process oriented stance in assessing the broader patterns of changing retail and consumer landscapes in the Scottish Borders as revealed through a sequence of three 
consumer shopping surveys since 1988. By focusing on regional level switching, this paper has emphasised the dynamism of retail and consumer landscapes and the changing relations within them. It is hoped that by this emphasis on switching a more dynamic approach is developed, over and above the typically rather single focus and static consumer choice and outshopping characteristics studies. Describing and understanding this dynamism is important.

In a search for clawback of spending within the Borders, consumers have been encouraged to alter their shopping patterns, preferences and thus the status of centres and retailers. Some clawback has been achieved but redistribution has probably been more formative in weaving a different fabric for the Borders' retail and consumer landscapes. Greater still has been the way that the endorsement of retail change through switching has lent credibility to further retail investment and planning approval, enhancing substantially the retail offer of Galashiels and bestowing on Galashiels a sense of primacy. This would seem to be difficult to challenge now, despite its serendipitous origins. Decisions about locations and developments have long-term often unintended consequences.

Change is still underway with pipeline developments only just coming onstream Whether it is changing consumer preferences for 'local' reengagement with local small agro-food producers and shops, or the impact of yet more multiple retailers at key nodes, or even the potential for changing travel linkages and patterns through the re-opening of the Waverley railway line to Edinburgh, consumer patterns of behaviour will remain subject to change. Through their switching behaviour consumers will continue to define success and failure and legitimate or not the 
strategic and policy decisions of key decision makers. How the consumer landscape will adapt to these new consumer realities and will embed these non-rural retail forms into their rural identities remains to be seen.

\section{Acknowledgements}

The authors would like to acknowledge the work of Andrew Smith (now at the University of Nottingham) on the 1998 survey analysis and report. They would also like to thank the Scottish Borders Council for the 1988 data and SHEFC for the funding under the Research Development Grant of the Centre for the Study of Retailing in Scotland. 


\section{References}

Accent Scotland and Mauthner, N. (2006) Service Priority, Accessibility and Quality in Rural Scotland. Scottish Executive, Edinburgh.

Action for Market Towns (2006) www.towns.org.uk, downloaded 1.8.06.

APPSSG (2006) High Street Britain: 2015. House of Commons, London.

Arnold, S., Handelman, J. and Tigert, D. (1998) The impact of a market spoiler on consumer preference structures (or what happens when Wal-Mart comes to town). Journal of Retail and Consumer Services 5, 1-13.

BBC (2006) 'Retail capital’ status welcomed, www.news.bbc.co.uk/l/hi/Scotland/south_of_scotland/6168710.stm, downloaded $15 / 01 / 07$

Broadbridge, A.M. and Calderwood, E. (2002) Rural grocery shoppers: do their attitudes reflect their actions? International Journal of Retail and Distribution Management 30, 394-406.

Burt, S.L. and Sparks, L. (1994) Structural change in grocery retailing in great Britain: a discount revolution? International Review of Retail, Distribution and Consumer Research 4, 195-217. 
Burt, S.L. and Sparks, L. (2003) Power and competition in the UK retail grocery market. British Journal of Management 14, 237-254.

Byrom, J., Medway, D. and Warnaby, G. (2001) Issues of provision and "remoteness" in rural food retailing. British Food Journal 103, 400-413.

Byrom, J., Medway, D. and Warnaby, G. (2003) Strategic alternatives for small retail businesses in rural areas. Management Research News 26(7), 33-49.

Caffyn, A. (2004) Market town regeneration: challenges for policy and implementation. Local Economy 19(1), 8-24.

Clark, G.M., MacLellan, M., McKie, L. and Skerratt, S. (1995) Food Availability and Choice in Remote and Rural Areas. HEBS, Edinburgh.

Clarke, I. (2000) Retail power, competition and local consumer choice in the UK grocery sector. European Journal of Marketing 34, 975-1002.

Clarke, I., Hallsworth, A., Jackson, P., de Kervenoael, R., Perez del Aguila, R. and Kirkup, M. (2006) Retail restructuring and consumer choice 1: Long-term local changes in consumer behaviour: Portsmouth, 1980 - 2002. Environment and Planning A 38, 25-46.

Cloke, P. (1997) Country backwater to virtual village? Rural studies and 'the cultural turn'. Journal of Rural Studies, 13, 367-375. 
Collis, C., Berkeley, N. and Fletcher, D. (2000) Retail decline and policy responses in district shopping centres. Town Planning Review 71, 149-168.

Competition Commission (2006) Groceries Market Investigation: statement of issues, London: Competition Commission. www.competitioncommission.org.uk/inquiries/ref2006/grocery/index.htm (downloaded 1.8.2006)

Dawson, J.A. (2000) Future Patterns of Retailing in Scotland. Scottish Executive, Edinburgh.

Dawson, J.A. (2001) Is there a new commerce in Europe? International Review of Retail, Distribution and Consumer Research, 11, 287-299.

Dawson, J.A. and Kirby, D.A. (1979) Small Scale Retailing in the UK. Saxon House, Farnborough

DETR (1998) The Impact of Large Foodstores on Market Towns and District Centres. DETR, London.

East, R., Harris, P., Willson, G. and Lomax, W. (1995) Loyalty to supermarkets. International Review of Retail, Distribution and Consumer Research 5, 99-109.

East, R., Hammond, K., Harris, P. and Lomax, W. (2000) First store loyalty and retention. Journal of Marketing Management 16, 307-325. 
Fernie, J. (1998) The breaking of the fourth wave: recent out-of-town retail developments in Britain. International Review of Retail, Distribution and Consumer Research 8, 303-317.

Financial Times (2006) Tesco property battles put its reputation at risk. Financial Times 20 May 2006, p5.

Findlay, A. (1993) The dynamics of superstore location in Scotland. In Scottish Geographical Studies, pp.305-316, Dawson, A., Jones, H., Small, A. and Soulsby, J. (eds). University of St Andrews, St Andrews.

Findlay, A. and Sparks, L. (2002) Retail planners’ bookshelf. International Journal of Retail and Distribution Management 30, 435-438.

Findlay, A.M., Stockdale, A., Findlay, A. and Short, D. (2001) Mobility as a driver of change in rural Britain: an analysis of the links between migration, community and travel to shop patterns. International Journal of Population Geography 7, 1-15.

Fraser, G.M. (1971) The Steel Bonnets - the story of the Anglo-Scottish Border Reivers. Harper Collins, London.

Fyson, A. (2006) Finding solutions for the exodous to the countryside, Planning, 28/07, 10 . 
Guy, C. (1990) Outshopping from small towns: a British case study. International Journal of Retail and Distribution Management 18(3), 3-14.

Halfacree, K. (1995) Talking about rurality: Social representations of the rural as expressed by residents of six English parishes. Journal of Rural Studies, 11, 1-20

Hallsworth, A. and Worthington, S. (2000) Local resistance to large retailers: the example of market towns and the food superstore in the UK. International Journal of Retail and Distribution Management 28, 207-216.

Hare, C. (2003) The food-shopping experience: a satisfaction survey of older Scottish consumers. International Journal of Retail and Distribution Management 31, 244-255.

Ilbery, B. and Maye, D. (2005) Food supply chains and sustainability: evidence from specialist food producers in the Scottish/English borders. Land Use Policy, 22, 331344.

Ilbery, B. and Maye, D. (2006) Retailing local food in the Scottish-English borders: a supply chain perspective. Geoforum 37, 352-367.

Jackson, P., Perez del Aguila, R., Clarke, I., Hallsworth, A., de Kervenoael, R. and Kirkup, M. (2006) Retail restructuring and consumer choice 2: understanding consumer choice at the household level. Environment and Planning A, 38, 47-67. 
Jarratt, D.J. (2000) Outshopping behaviour: an explanation of behaviour by shopping segments using structural equation modelling. International Review of Retail, Distribution and Consumer Research 10, 287-304.

Kirby, D.A. (1981) Aid for Village Shops. URPI, Reading.

Linklater, M. (2005) Linklater’s Scotland. Scotland on Sunday 17 April 2005, p4.

Lumpkin, J.R., Hawes, J.M. and Darden, W.R. (1986) Shopping patterns of rural consumers: exploring the relationship between shopping orientations and outshopping. Journal of Business Research 14, 63-81.

McEachern, M.G. and Warnaby, G. (2006) Food shopping behaviour in Scotland: the influence of relative rurality. International Journal of Consumer Studies 30, 189-201.

Nielsen (2006) Retail Pocket Book 2006. Oxford, AC Nielsen.

Parry, O., Bancroft, A., Gnich, W. and Amos, A. (2001) Nobody home? Issues of respondent recruitment in areas of deprivation. Critical Public Health 11, 305-317.

Phillips, M. and Swaffin-Smith, C. (2004) Market towns - victims of market forces? International Journal of Retail and Distribution Management 32, 557-568. 
Philo, C. (1992) Neglected rural geographies: A review • Journal of Rural Studies, 8, 193-207.

Pike, A. (2002) Post-devolution blues? Economic development in the Anglo-Scottish Borders. Regional Studies 36, 1067-82.

Powe, N. and Shaw, T. (2003) Market towns: investigating the service role through visitor surveys. Planning Practice and Research 18(1), 37-50.

Powe, N. and Shaw, T. (2004) Exploring the current and future role of market towns servicing their hinterlands: a case study of Alnwick in the North East of England. Journal of Rural Studies 20, 405-418.

Roger Tym \& Partners (1996) The Gyle Impact Study. Scottish Executive, Edinburgh. Scotsman (2000) Town's 6.5M pound facelift under threat after Trinity. Scotsman 12 October 2000, p12

Scotsman (2004) Giant ASDA store will hit Border towns say critics. Scotsman 11 February 2004, p9

Scottish Borders Council (2002) Scottish Borders Structure Plan. Scottish Borders Council, Newton St Boswells. 
Scottish Borders Council (2005) Application for Planning Permission : Erection of Class 1 Non-Food Retail Development with Associated Car Parking, Servicing, Landscaping and Ancillary Works. Scottish Borders Council, Newton St Boswells.

Scottish Executive (2006) Urban-Rural Classification 2005-2006, Edinburgh, Scottish executive (CD-ROM).

Seiders, K. and Tigert, D.J. (1997) Impact of market entry and competitive structure on store switching/store loyalty. International Review of Retail, Distribution and Consumer Research 7, 227-247.

Skerratt, S. (1999) Food availability and choice in rural Scotland: the impact of “place”. British Food Journal 101, 537-544.

Smith, A. and Sparks, L. (1997) Retailing and Small Shops. Edinburgh, Scottish Office.

Southern Reporter (2006a) Tesco launches Kelso store bid. Southern Reporter 26 January 2006.

Southern Reporter (2006b) Tesco relents over historic frontage. Southern Reporter 29 June 2006. 
Thomas, C. and Bromley, R. (1995) Retail decline and the opportunities for commercial revitalisation of small shopping centres: a case study in South Wales. Town Planning Review, 66, 431-452.

Thomas, C. and Bromley, R. (2002) The changing competitive relationship between small town centres and out-of-town retailing: town revival in south Wales. Urban Studies 39, 791-817.

Thomas, C., Bromley, R. and Tallon, A. (2006) New 'high streets' in the suburbs? The growing competitive impact of evolving retail parks. International Review of Retail, Distribution and Consumer Research 16, 43-68.

Wood, S., Lowe, M. and Wrigley, N. (2006) Life after PPG6 - recent UK food retailer responses to planning regulation tightening. International Review of Retail, Distribution and Consumer Research 16, 23-41

Worthington, S. (1998) Loyalty cards and the revitalisation of the town centre. International Journal of Retail and Distribution Management 26, 68-77. 
Table 1: Food Shopping in the Borders

\begin{tabular}{|l|r|r|r|}
\hline & \multicolumn{1}{|l|}{$\mathbf{1 9 8 8}$} & $\mathbf{1 9 9 8}$ & $\mathbf{2 0 0 4}$ \\
\hline $\begin{array}{l}\text { (a) Main food shopping location (\% of } \\
\text { respondents) }\end{array}$ & & & \\
\hline & & & \\
\hline Galashiels & 22.7 & 22.8 & 40.4 \\
\hline Hawick & 18.2 & 20.9 & 14.4 \\
\hline Berwick-upon-Tweed & 8.5 & 13.1 & 5.6 \\
\hline Kelso & 12.5 & 12.5 & 7.6 \\
\hline Peebles & 7.7 & 9.9 & 12.0 \\
\hline Edinburgh & 5.8 & 6.4 & 5.4 \\
\hline Others & 24.6 & 14.4 & 14.5 \\
\hline & & & \\
\hline (b) Mode of Travel to Main Food Shop & & & \\
(\%) of respondents) & & & \\
\hline Bus & 7.8 & 4.0 & 6.1 \\
\hline Foot & 25.6 & 11.7 & 10.8 \\
\hline Car (Driver or Passenger) & 65.8 & 83.1 & 81.1 \\
\hline Others & 0.8 & 1.2 & 2.0 \\
\hline & & & \\
\hline (c) Share of Main food Shop Spend (\% \\
of respondents)
\end{tabular}


Table 2: Borders Food Shopping Catchment Zones 1998 and 2004

\begin{tabular}{|l|l|l|l|}
\hline & $\begin{array}{l}\text { Main } \\
\text { Postcode (\%) }\end{array}$ & $\begin{array}{l}\text { Top Two } \\
\text { Postcodes (\%) }\end{array}$ & $\begin{array}{l}\text { Top Three } \\
\text { Postcodes (\%) }\end{array}$ \\
\hline & & & \\
\hline Galashiels & & & \\
\hline 1998 & 47.9 & 72.7 & 83.8 \\
\hline 2004 & 40.5 & 65.6 & 81.0 \\
\hline & & & \\
\hline Hawick & & & \\
\hline 1998 & 72.1 & 80.9 & 88.7 \\
\hline 2004 & 75.6 & 87.8 & 95.1 \\
\hline & & & \\
\hline Peebles & & & \\
\hline 1998 & 73.2 & 84.8 & 90.6 \\
\hline 2004 & 77.9 & 85.3 & 92.6 \\
\hline & & & \\
\hline Kelso & & & 88.0 \\
\hline 1998 & 75.9 & 82.8 & 99.8 \\
\hline 2004 & 92.9 & 97.4 & \\
\hline & & & \\
\hline
\end{tabular}


Table 3: A Comparison of Shopper Characteristics for Safeway in Hawick between 1998 and 2004 and Tesco, Galashiels

\begin{tabular}{|l|l|l|l|}
\hline & $\begin{array}{l}\text { Safeway, } \\
\text { Hawick 1998 }\end{array}$ & $\begin{array}{l}\text { Safeway, } \\
\text { Hawick 2004 }\end{array}$ & $\begin{array}{l}\text { Tesco, } \\
\text { Galashiels } \\
\mathbf{2 0 0 4}\end{array}$ \\
\hline & $\%(\mathrm{n}=189)$ & \% (n=53) & $\%(\mathrm{n}=178)$ \\
\hline (a) Economic Activity & & & \\
\hline $\begin{array}{l}\text { Professional and } \\
\text { Managerial }\end{array}$ & 34.8 & 26.4 & 42.6 \\
\hline Skilled Manual & 17.7 & 20.8 & 14.8 \\
\hline Non-skilled manual & 6.6 & 7.5 & 3.4 \\
\hline Retired & 26.0 & 35.8 & 28.9 \\
\hline $\begin{array}{l}\text { Unemployed/Not } \\
\text { employed }\end{array}$ & 2.3 & 3.8 & 2.8 \\
\hline Self-employed & 12.7 & 5.7 & 7.4 \\
\hline & & & \\
\hline (b) Age & & & 23.0 \\
\hline Less than 40 & 29.6 & 17.0 & 21.9 \\
\hline $40-49$ & 20.1 & 24.5 & 27.5 \\
\hline $50-59$ & 21.2 & 22.6 & 27.5 \\
\hline 60 and over & 29.1 & 35.8 & \\
\hline & & & 70.8 \\
\hline (c) Mobility & & & 29.2 \\
\hline Car & 83.1 & 81.1 & 15.7 \\
\hline No car & 16.9 & 18.9 & \\
\hline & & & \\
\hline $\begin{array}{l}\text { (d) Household } \\
\text { Composition }\end{array}$ & & 20.8 & \\
\hline Single person & 13.1 & 79.2 & \\
\hline 2 or more people & 86.9 & & \\
\hline & 56.4 & & \\
\hline No children & 43.6 & & \\
\hline Family & & & \\
\hline
\end{tabular}


Table 4: Non-Food Shopping in the Borders

\begin{tabular}{|c|c|c|c|}
\hline $\begin{array}{l}\text { Main Shopping Destination (\% of } \\
\text { respondents) }\end{array}$ & 1988 & 1998 & 2004 \\
\hline \multicolumn{4}{|l|}{ (a) Clothing and Footwear } \\
\hline Galashiels & 14.1 & 13.5 & 31.0 \\
\hline Hawick & 9.0 & 7.9 & 5.3 \\
\hline Berwick upon Tweed & 8.3 & 8.4 & 3.1 \\
\hline Kelso & 5.6 & 4.5 & 4.3 \\
\hline Peebles & 4.8 & 5.0 & 5.3 \\
\hline Edinburgh & 27.8 & 41.0 & 40.9 \\
\hline Others & 30.4 & 24.7 & 4.7 \\
\hline \multicolumn{4}{|l|}{ (b) DIY } \\
\hline Galashiels & 17.0 & 49.1 & 64.9 \\
\hline Hawick & 11.1 & 8.1 & 2.8 \\
\hline Berwick upon Tweed & 9.6 & 16.4 & 6.4 \\
\hline Kelso & 7.7 & 4.8 & 4.2 \\
\hline Peebles & 3.8 & 3.3 & 3.3 \\
\hline Edinburgh & 29.7 & 8.2 & 11.0 \\
\hline Others & 21.1 & 10.1 & 7.4 \\
\hline \multicolumn{4}{|l|}{ (c) Electricals } \\
\hline Galashiels & 29.4 & 38.6 & 63.7 \\
\hline Hawick & 13.7 & 10.5 & 1.7 \\
\hline Berwick upon Tweed & 11.7 & 15.5 & 4.9 \\
\hline Kelso & 9.4 & 7.5 & 4.5 \\
\hline Peebles & 3.7 & 3.7 & 0.6 \\
\hline Edinburgh & 11.9 & 14.6 & 19.7 \\
\hline Others & 16.6 & 9.6 & 4.9 \\
\hline \multicolumn{4}{|l|}{ (d) Furniture and Furnishings } \\
\hline Galashiels & 25.1 & 25.1 & 28.3 \\
\hline Hawick & 16.7 & 22.0 & 15.3 \\
\hline Berwick upon Tweed & 12.8 & 13.7 & 5.2 \\
\hline Kelso & 6.1 & 3.7 & 4.0 \\
\hline Peebles & 5.7 & 5.3 & 5.4 \\
\hline Edinburgh & 17.7 & 17.4 & 22.7 \\
\hline Others & 15.9 & 12.8 & 6.4 \\
\hline
\end{tabular}


Figure 1: The Scottish Borders

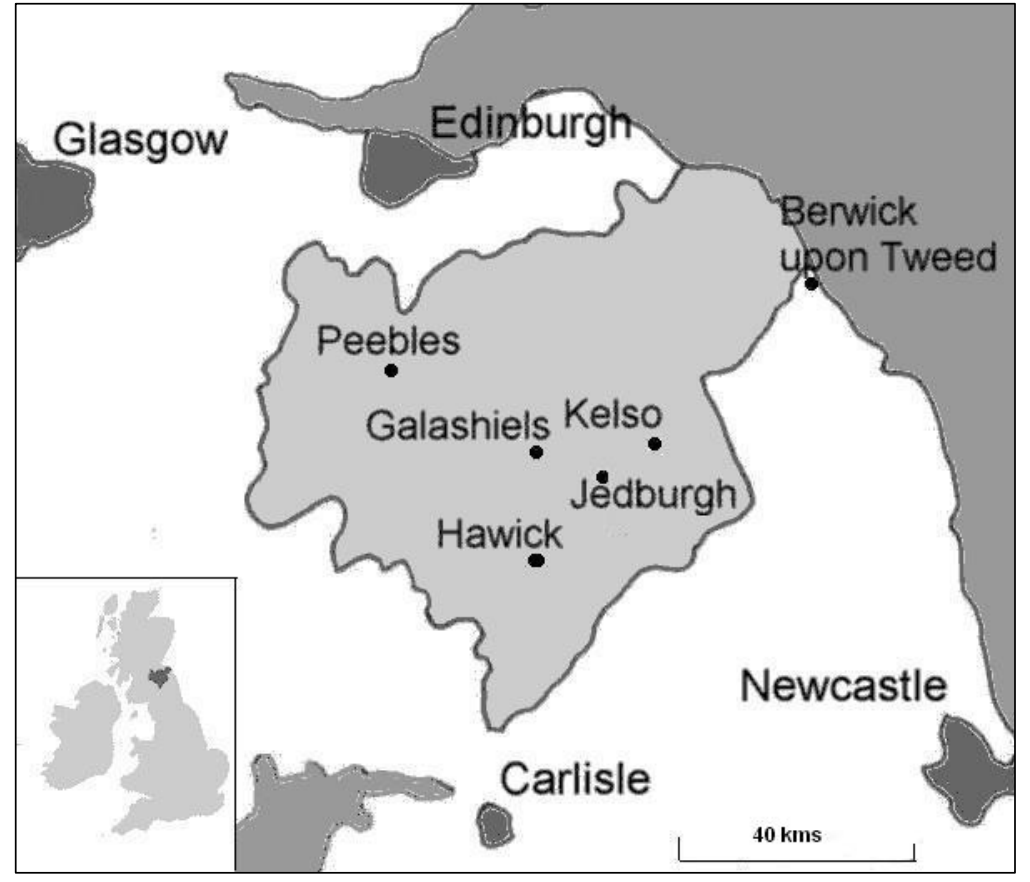


Figure 2: Retail development in Galashiels

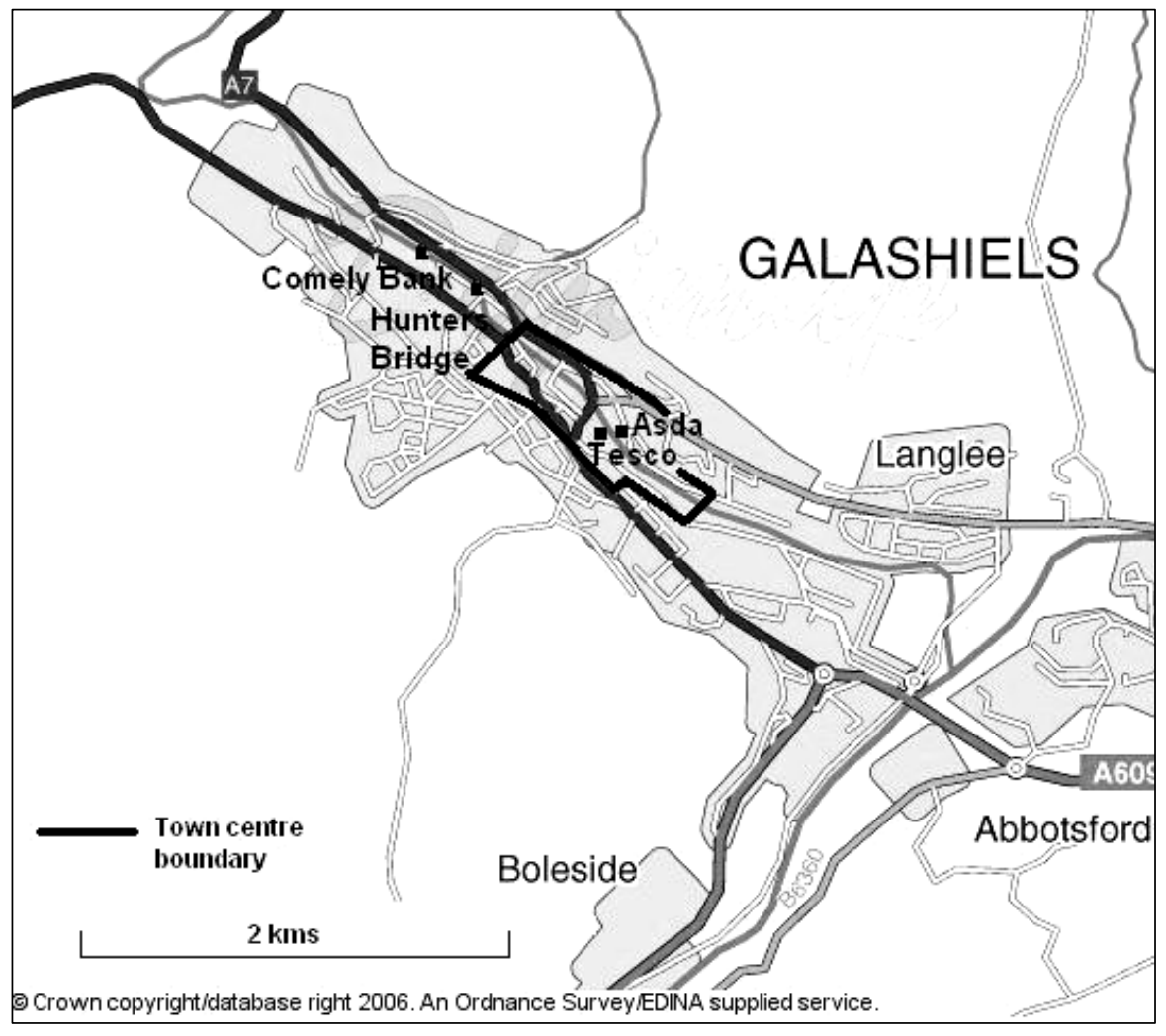

